\title{
Sitagroi, radiocarbon and the prehistory of south-east Europe
}

\author{
COLIN RENFREW
}

\begin{abstract}
Dr Renfrew, of the University of Sheffield, directed excavations at Sitagroi in north Greece in 1968 and 1969 and in an earlier note here $(I 970, I 3 I)$ says that one of the important aspects of the finds there was that 'for the first time Balkan cultures are seen in direct stratigraphic relation to those of the Aegean'. A series of twenty-six radiocarbon dates, determined by the British Museum and Berlin laboratories, from the Sitagroi mound offers the possibility of a new and detailed understanding of the chronological relations between the Aegean and the Balkans.
\end{abstract}

The importance of the chronological relations between the Aegean and the Balkans for European prehistory as a whole was indicated in 1929 by Gordon Childe in The Danube in Prehistory, and in later works. He based his chronological structure of the contemporaneity of Vinča with early Troy, one of the basic foundations of the conventional chronology for Europe. Radiocarbon dates called this link into question (Mellaart, 1960) although it has since been defended by some scholars (Garašanin, 196r; Milojčić, 1967). Excavations in Bulgaria supported the view that the Balkan Copper Age (Chalcolithic, Aeneolithic) preceeded the Aegean bronze age by a considerable span of time (Renfrew, I969), and this view has been confirmed by the ro-m. stratigraphy at Sitagroi (Renfrew, I970).

The Sitagroi radiocarbon dates now allow of greater chronological precision. The evident relations of the site with the Balkans, and its location in the Aegean basin, give it a key position. For the first time it is becoming possible both to see the Balkan chronology through Aegean eyes, and to view the Aegean development from a Balkan standpoint. It now seems feasible to answer some of the questions posed by Mellaart in his 1960 article. The answers have a direct bearing upon our entire picture of the development of the early bronze age of Europe, from the Mediterranean to the North Sea.

THE SITAGROI DATES AND THEIR CONTEXT

Excavations at Sitagroi were undertaken in r 968 and 1969 , organized jointly by Professor Marija Gimbutas of the University of California at Los Angeles and the writer, and directed in the field by the latter. The project was supported by grant GS-I949 from the National Science Foundation, by the British School at Athens and the University of Sheffield, and owes much to Mrs C. Koukouli-Chrysanthaki, the local representative of the Greek Archaeological Service, which authorized the excavation. The excavation will be reported in full elsewhere: the intention here is simply to indicate the context of the radiocarbon samples.

In addition to several much larger areas, a sounding was excavated from the summit of the mound. This square, trench $\mathrm{ZA}$, was of side $3 \mathrm{~m}$., and revealed more than $10 \mathrm{~m}$. of stratified deposits. Quantitative study of the pottery permitted a division of the strata into five separate phases, of which the fifth and latest was subsequently subdivided. This stratigraphic sequence was confirmed by excavations on other parts of the site, so that the culture sequence does not rest on the evidence of $\mathrm{ZA}$ alone. 


\section{ANTIQUITY}

A brief synopsis of the sequence has already been published (Renfrew, 1970). The pottery development may be summarized as follows:

Phase Vb: Plain, unpainted pottery. Onehandled cups common. At first sight there are resemblances to early bronze age Troy and the late Baden culture.

Phase Va: The 'Burnt House' phase. Unpainted pottery, sometimes decorated with incisions somewhat reminiscent of the pottery of the Vučedol culture.

Phase IV: Plain dark wares, again with some Baden resemblances.

Phase III: The Dikilitash phase. Graphitepainted pottery and other features indicate contacts with the Maritsa-Gumelnitsa complex of Bulgaria and Romania. Many other wares are entirely local.

Phase II: A variety of painted wares, showing slight resemblances to those of middle or late neolithic Thessaly.

Phase I: Dark faced wares. Some shapes resemble those of the Vesselinovo (Karanovo III) culture of Bulgaria,

Many of the radiocarbon samples came from trench ZA itself. An approximate stratigraphic equation is possible for the adjacent square $\mathrm{ZB}$, where a number of samples came from the wet-sieving operation conducted by Sebastian Payne. The samples from other areas are not linked directly with ZA by stratigraphic means, but can be assigned a place in the ZA sequence on the basis of their associated finds.

In presenting these dates I should like to express out gratitude to the Radiocarbon Laboratories of the British Museum and of the Deutsche Akademie der Wissenschaften in East Berlin, as well as to Mr Richard Burleigh and Drs H. Quitta and G. Kohl for their cooperation and advice. The dates on the left are in precise stratigraphic order (Table $\mathbf{I}$ ).

Of these dates only Bln 885 (6030 BC) fails to conform with the emerging pattern. Dr Kohl writes: 'Bln 885 is very uncertain since the quantity of carbon for analysis from this sample was very limited.' This sample is omitted from further discussion. (It should be noted that level $\mathrm{ZB}$ I12 was first assigned to the upper levels of phase III. The lower fill of a large pit, it contained at least one phase IV sherd. It is now regarded as very early phase IV. In addition, it is not at present clear whether the pottery in level ZA 16 should lead to its placing in late phase IV or early phase Va).

On two occasions the same sample was divided and determined by both laboratories: BM 650a and Bln 880; BM 648 and Bln 779. In a further three examples the two laboratories ran different samples from the same stratigraphical horizon: QO 8, ZA $5 \circ$, and POr 58 with 162. Each time the Berlin date was appreciably earlier than the British Museum date, and there is evidently the possibility of a systematic difference here between the determinations of the two laboratories. But even if this should be so (and no explanation can be found in terms of pre-treatment or analytical procedures), it does not result in major deviations from the stratigraphic order.

The dates, indeed, give a coherent sequence, and allow the time span in question to be divided into a number of periods, seen on the left in Table 2. No date falls outside the period appropriate to its phase by more than one standard deviation, except for those dates in phase $V$, where there are special circumstances. It is at this time that there were, according to the calibration work of Professor Suess (1970), marked changes in the atmospheric concentration of radiocarbon. This implies that samples differing in true age by as much as 300 years could yield the same radiocarbon date of r900 BC. The calibration curve (cf. Renfrew, I970, 284) suggests that if the transition from phase $\mathrm{Va}$ to $\mathrm{Vb}$ took place around $2300 \mathrm{BC}$ in calendar years, samples from phase Va could yield accurate carbon dates later than $1900 \mathrm{BC}$, while samples from phase $\mathrm{Vb}$ could yield radiocarbon dates falling before $2000 \mathrm{BC}$. In radiocarbon years there is an overlap between two periods which in reality were consecutive.

Unfortunately no samples were available from the later levels of phase III (ZA levels 40 to 33). The material from these levels does show some development, however, so that this period, here termed 'Later Phase III' need not represent an interruption of occupation on the site. 


\begin{tabular}{|c|c|c|c|c|c|}
\hline Phase & Level & $\begin{array}{c}\text { Dates in } \\
\text { Precise } \\
\text { Stratigraphic } \\
\text { Order } \\
\text { BC }\end{array}$ & $\begin{array}{c}\text { Other } \\
\text { Dates } \\
\text { BC }\end{array}$ & Lab. No. & Material \\
\hline $\mathrm{Vb}$ & QO 8 & & $1840 \pm 78$ & BM 653 & Vetch \\
\hline $\mathrm{Vb}$ & QO 8 & & $2135 \pm 150$ & Bln 781 & Vetch \\
\hline $\mathrm{Vb}$ & $\mathrm{PO}_{9}$ & $1920 \pm 100$ & & Bln 780 & Charcoal \\
\hline $\mathrm{Vb}$ & PO 23 & $2015 \pm 100$ & & $B \ln 876$ & Charcoal \\
\hline $\mathrm{Va}$ & $\mathrm{PO} \times 5^{8}$ & $2220 \pm 100$ & & $B \ln 877$ & Charcoal \\
\hline $\mathrm{Va}$ & PO I62 & $1853 \pm 59$ & & BM 652 & Charcoal, from post-hole \\
\hline $\mathrm{IV} / \mathrm{Va}$ & $\mathrm{ZA}$ I6 & $2360 \pm 100$ & & $B \ln 782$ & Charcoal from beam \\
\hline IV & ZA 29 & $2440 \pm 100$ & & $B \ln 773$ & Acorns \\
\hline IV & $\mathrm{ZA}_{3 \mathrm{I}}$ & $2600 \pm 100$ & & $B \ln 879$ & Charcoal \\
\hline IV & ROc 59 & & 2445 土 100 & $\mathrm{B} \ln 878$ & Charcoal \\
\hline IV & ZB 108 & $23^{82} \pm 79$ & & $\mathrm{BM} 65 \mathrm{I}$ & Acorns, from flotation \\
\hline IV & $\mathrm{ZB}$ I12 & $2413 \pm 56$ & & BM 6502 & Charcoal, from flotation \\
\hline IV & $\mathrm{ZB} I 12$ & $2560 \pm 100$ & & $B \ln 880$ & Charcoal, from flotation \\
\hline III & $\mathrm{ZA}_{41 a}$ & $3150 \pm 120$ & & Bln 774 & Charcoal \\
\hline III & $Z B+25$ & $3605 \pm 100$ & & $B \ln 88 I$ & Charcoal, from flotation \\
\hline III & ML I 18 & & $34 \mathrm{I} 7 \pm 85$ & BM 65ob & Charcoal \\
\hline III & $\mathrm{MM}_{52}$ & & $3845 \pm 100$ & $\mathrm{~B} \ln 882$ & Charcoal \\
\hline III & MMb 69 & & $3595 \pm 100$ & $\mathrm{~B} \ln 88_{3}$ & Einkorn, from flotation \\
\hline II & $\mathrm{ZA}_{50}$ & $3954 \pm 66$ & & BM 649 & Charcoal, from flotation \\
\hline II & $\mathrm{ZA}_{5} \mathrm{O}^{\circ}$ & $4290 \pm 100$ & & Bln 884 & Charcoal \\
\hline II & $\mathrm{ZA}_{52}$ & $3770 \pm 100$ & & $B \ln 776$ & Charcoal \\
\hline II & ZA 59 & $3970 \pm 120$ & & $B \ln 777$ & Charcoal \\
\hline (I) & ZA 63 & $(6030 \pm 150)$ & & $B \ln 88_{5}$ & Charcoal \\
\hline I & ZA 67 & $43^{15} \pm 75$ & & BM 648 & Charcoal \\
\hline I & ZA 67 & $4675 \pm 170$ & & $B \ln 779$ & Charcoal \\
\hline I & ZA 70 & $4475 \pm 100$ & & $\operatorname{Bln} 778$ & Charcoal \\
\hline
\end{tabular}

Table I. Radiocarbon dates from Sitagroi in stratigraphic order

All dates are in radiocarbon years on the 5568 half-life. Two samples were divided, and half sent to each laboratory: BM 650a and Bln 880; and BM 648 and Bln 779.

The stratigraphic interpretation of tell sites such as Sitagroi does however still present some problems. For although there is a considerable continuity in the finds from successive phases, we cannot be certain whether the site was occupied continuously, or intermittently for short periods. As Professor Saul Weinberg has remarked in another context: 'Contiguity does not prove continuity.' Indeed on the model of short occupations separated by an abandonment of the site, it is possible to set the dates within a narrow minimum time range (Table 2 , centre). Once again, with the one special exception already discussed, no date falls outside its appropriate period by more than approximately one standard deviation. This exercise does not, of course, demonstrate that the site was in fact abandoned. These are, 


\section{ANTIQUITY}

on the continuous occupation model, simply fortuitous bunchings of dates. Statistically they may be regarded as maximum confidence time spans, and we may be reasonably sure that the culture in question was in occupation of the mound during its maximum confidence span. They are seen in FIG. I, where they form a background to the presentation of dates from other relevant areas.

This kind of treatment, which is of great value in assessing the chronology of such a site, is only possible when we have a good series of dates whose stratigraphic order is precisely known. In this way it is possible to counteract to some extent the effect of random and other fluctuations upon the resulting chronology.

\section{THE IMPLICATIONS OF THE SITAGROI \\ DATES}

The Sitagroi dates are presented in stratigraphic order (FIG. I), together with selected dates from the Aegean and the Balkans. These dates are listed in Table 4. Those for the Balkans and central Europe are from a number of recent publications (Kohl and Quitta, 1966, 1967; Quitta and Kohl, 1969; Neustupný, I968, 1969). A fuller discussion of the Aegean final neolithic and early bronze age chronology, with dates, will be found elsewhere (Renfrew, 1972). These comparisons allow the clarification of a number of problems.

1. The Aegean and the Balkans in the Neolithic Period. The Sitagroi dates very strongly support the view that the Balkan chalcolithic
(Vinča-Pločnik, Gumelnitsa, Karanovo V-VI) was contemporary with the later neolithic of the Aegean, long preceding the Aegean early bronze age or early Troy. The material of phase III at Sitagroi is undoubtedly very close to that of the Bulgarian chalcolithic, so that the stratigraphic and the radiocarbon evidence from the site speak in unison.

Excavation in the Balkans had already made clear that the Balkan late neolithic (VinčaTordoš, Vesselinovo, Karanovo III) was still earlier. The material of Sitagroi phase I is again clearly related to it, and the radiocarbon dates agree with the stratigraphic findings.

We are now in a position to recover from the initial and understandable shock at the collapse of the old Vinča-Troy equation, and of so much that went with it. Indeed, seen through Balkan eyes the Aegean cultures of the time seem rather lacking in variety or invention. Only in Thessaly and the north, where the Dhimini culture and its contemporaries were under way, do we see the Balkan range of figurines, or the elaborately decorated pottery, or the early metallurgy. (The earliest copper in the Aegean is from the end of phase II at Sitagroi: copper is found too at Dhimini.) Indeed it would now be reasonable to regard Dhimini or Sitagroi III as chalcolithic in precisely the same sense as their Balkan contemporaries.

2. The transition from Neolithic to Bronze Age in the Aegean. The first impression of the phase V material at Sitagroi was that it resembled the finds of Troy I sufficiently closely for

\begin{tabular}{|c|c|c|c|}
\hline Phase & $\begin{array}{c}\text { Maximum Duration of } \\
\text { Phase (Radiocarbon } \\
\text { Years BC) }\end{array}$ & $\begin{array}{c}\text { Minimum Duration of } \\
\text { Phase (Radiocarbon } \\
\text { Years BC) }\end{array}$ & $\begin{array}{l}\text { Possible Minimum } \\
\text { Duration of Phase } \\
\text { (Calendar Years BC) }\end{array}$ \\
\hline $\mathrm{Vb}$ & $2000-1800$ & $2000-1900$ & $2250-2150$ \\
\hline $\mathrm{Va}$ & $2300-1900$ & $2150-1900$ & $2600-2450$ \\
\hline $\begin{array}{l}\text { IV } \\
\text { Later III }\end{array}$ & $\begin{array}{l}2600-2300 \\
3100-? 2600\end{array}$ & $\begin{array}{l}2500-2400 \\
\text { Uncertain }\end{array}$ & $3300-3100$ \\
\hline Earlier III & $3800-3100$ & $375^{\circ}-3250$ & $4700-4200$ \\
\hline II & $4300-3800$ & $4200-3850$ & $5200-4800$ \\
\hline I & $4700-4300$ & $4500-4400$ & $? 5400-? 5300$ \\
\hline
\end{tabular}

Table 2. Durations of the Sitagroi phases

The boundaries for the periods have been chosen so that none of the relevant radiocarbon dates falls outside its phase by more than one standard deviation.
(Only the date of $195^{\circ}$ for the $\mathrm{Va} / \mathrm{Vb}$ transition presents a problem, possibly because of secular variations in the atmospheric concentration of radiocarbon) 


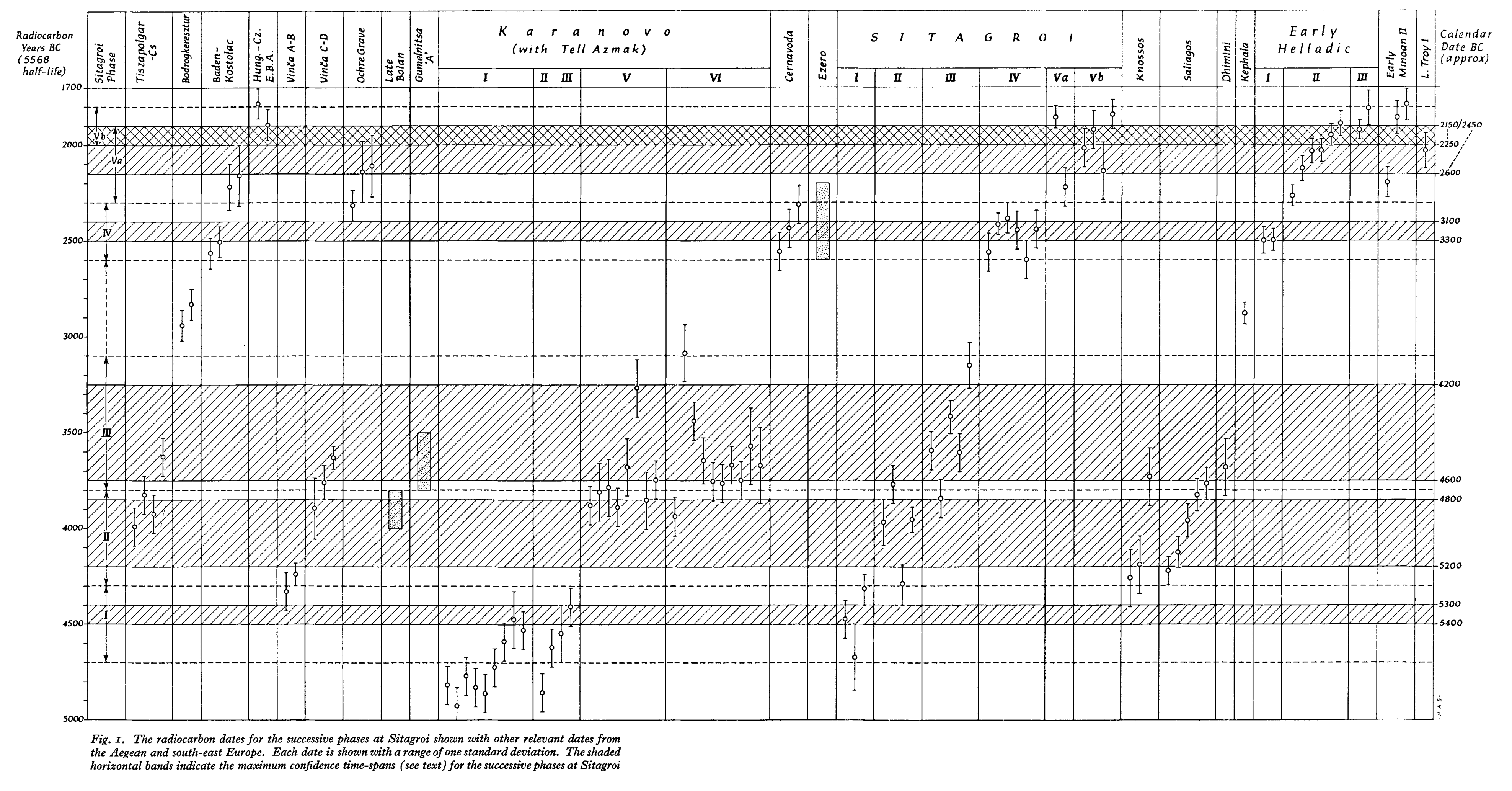




\section{SITAGROI AND THE PREHISTORY OF SOUTH-EAST EUROPE}

the two to be contemporary. Further study makes this resemblanceless compelling, although there remains an evident general similarity between the pottery of Sitagroi IV and V and that of Kritsana or the Trojan early bronze age.

The radiocarbon dates for this material at first seemed rather late. So indeed did those for the entire Aegean early bronze age, before the application of the tree-ring calibration of radiocarbon. Dates of $\mathrm{I} 785 \mathrm{BC}$ for Early Minoan II Myrtos, or of 2025 BC supposedly from late Troy I levels at Emborio did not make sense: they were far too late. The calibration brings them all into much better harmony with the existing historical chronology.

It seems likely now that Sitagroi phase IVwhose material has resemblances with Early Thessalian I-was in part contemporary with the Eutresis culture (Early Helladic I), although it may have begun a little earlier. Sitagroi Va and $\mathrm{Vb}$ may be very roughly contemporary with the Korakou culture (Early Helladic II) and the Tiryns culture (Early Helladic III) respectively. It does now seem likely that the Troy I culture began in later Early Helladic I times and extended into Early Helladic II (cf. Renfrew, 1972, ch. 13), so that the Emborio date is no longer quite so shockingly late.

The big gap in radiocarbon years, and indeed in calendar years, between the late neolithic dates in the Aegean and those of the early bronze age is now very striking. I have suggested (loc. cit.) that we must think in terms of a final neolithic period, represented at Sitagroi by the later phase III material and early IV, in the Troad by Kum Tepe, in Crete by the 'subneolithic', and in south Greece by material which is now coming to light, for example, at the Franchthi Cave. The transition from neolithic to bronze age in the Aegean was a long one, of which we know as yet little. The long stratigraphic sequence at Sitagroi does give substance (as I believe will that of Emborio when it is published) to this hitherto unrecognized period which evidently lasted at least five centuries.

3. The transition from Neolithic to Bronze Age in the Balkans. A number of rather similar observations may be made in south-east Europe as a whole. All the published dates for the Cernavoda-Ezero culture levels at Ezero-which in Bulgarian terms represents the beginning of the early bronze age-may be set between $2600 \mathrm{BC}$ and $2200 \mathrm{BC}$ without statistical improbablity. The dates for Karanovo $\mathrm{V}$ and VI and contemporary copper age levels at Tell Azmak may all be set before $3200 \mathrm{BC}$ in radiocarbon years without statistical improbability. Between these two phases in Bulgaria and Romania is a transitional period, an 'Úbergangszeit', which archaeologists are now beginning to discern (Morintz and Roman, I969). The sites of Cernavoda, Coţofeni and Folteşti have yielded relevant material, and the earlier finds from Ezerovo near Varna may belong here too.

Further north and west the gap between copper age and early bronze age is not so marked. In Hungary the early Baden culture, and notably the Boleraz group, can now be seen to fall in this period. Dr Evžen Neustupný (1968) has set out in convincing detail the arguments there for a long chronology.

Sitagroi, like these other sites, can be seen from the Balkan standpoint to participate in the long transition. The pottery of phases IV and $V$, and its Balkan relations, is at present the subject of special study by $\mathrm{Mr}$ Andrew Sherratt, and will be presented in detail by him in the final excavation report. Certainly the material of later phase III and of phase IV allows us to see the development at Sitagroi as a gradual local evolution. The long period which this development likewise occupied in the Balkans makes an explanation in local terms much more acceptable.

\section{The Aegean and the Balkans in the Early} Bronze Age. In the past it has been usual to see the Aegean and the Balkans as different culture areas (which in many senses they indeed are) and to discuss in isolation the development of the bronze age in each. For the first time, however, it is becoming possible to build up a chronological picture of the developments at this time in south-east Europe as a whole. Whether or not these were local, indigenous 


\section{ANTIQUITY}

developments, a unified time perspective is useful.

The final neolithic of the Aegean was contemporary with the Romanian 'Utbergangszeit' and with the early development of the Baden culture in central Europe. The view that the Baden culture derived from the Aegean early bronze age is no more acceptable than the previous arguments for the origins of Vinča. This final neolithic period falls between 3000 and $2600 \mathrm{BC}$ in radiocarbon years, perhaps between 4000 and $3400 \mathrm{BC}$ in calendar years.

Then, during the time of Sitagroi IV (2600$2300 \mathrm{BC}$ in radiocarbon years), we see the development of the Eutresis culture (Early Helladic I) and perhaps already of early Troy I. This is the time of the Ezero culture in Bulgaria and of the developed Baden culture in Hungary and adjacent areas (Baden-Kostolac, etc.). It is the period indicated as 'Middle Aenolithic' in Neustupný's useful chronological table for central Europe (Neustupný, 1968, 48-49). In calendar years it may last from 3400 to $2800 \mathrm{BC}$.

With Sitagroi $\mathrm{V}$ we are in the developed early bronze age of the Aegean (Early Helladic II and III), from 2300 to 1800 or $1700 \mathrm{BC}$ in radiocarbon years. This is the time of late Troy I, Troy II and Troy III-VI. In central Europe this takes us through, and perhaps beyond Neustupny's 'Late Aenolithic', with Corded Ware, and then Bell Beakers. In west Hungary and also in Yugoslavia, the Vučedol culture occupies the earlier part of this phase, and has resemblances with the incised pottery of Sitagroi Va. Corded ware is seen at Sitagroi in small quantities in phase $\mathrm{V}$.

It is likely that the fully bronze age cultures of Central Europe-including Nagyrév, Monteoru and Unětice (Aunjetitz) -were emerging in the later part of this period, which may extend from 2800 to $2100 \mathrm{BC}$ in calendar years. East Hungary, and in particular Transylvania, seems to have been especially important, and although there are yet no relevant dates, we must expect radiocarbon determinations dating back to I800 BC or I900 BC for the Periam (Perjamos, Pecica) culture, corresponding to a beginning around $2300 \mathrm{BC}$ in calendar years. The contemporary of Sitagroi $\mathrm{Vb}$ in Hungary may well be the Periam culture in Transylvania, and then the Early Nagyrév culture in eastern Hungary generally. It seems likely that the Monteoru culture in Romania and the Únětice culture in Czechoslovakia were developing shortly afterwards.

Certainly by the Aegean middle bronze age (i.e., beginning in 1800 or $1700 \mathrm{BC}$, radiocarbon years, $c .2100 \mathrm{BC}$, calendar years), when Sitagroi was abandoned, these cultures were in being. Before the end of the Aegean middle bronze age, around $1600 \mathrm{BC}$, the Nagyrév culture must have completed its evolution through the Hatvan stage to Otomani (Füzesabony), and the Tumulus culture have emerged to succeed Unnetice in Czechoslovakia and Germany. Much of this is provisional at present, especially the absolute dates, but at least the outline is emerging. It is indicated, in geographically very compressed form, in Table 3 .

At first sight this picture may seem somewhat complicated, but the broader outlines are beginning to emerge. Some de-Balkanization of south-east European prehistory is now becoming possible. We can now look out from Britain, with our vested interest in Beakers and in the Unětice culture (by reason of Wessex) and discern the contemporary developments in Hungary, where Beakers may have originated, and where the bronze age began so early to flourish. The position of Sitagroi, looking Janus-like both to north and south, permits us to translate this into contemporary Aegean terms, where it comes out as early bronze age. Our own Beaker copper age comes long after the copper age of the Balkans and succeeds the Baden culture of that area. In Aegean terms it falls at the end of the early bronze age.

The development of our early bronze age (i.e. the Wessex culture and its contemporaries) was thus taking place at the time when the Nagyrév and Únětice cultures were already well underway, in what in Aegean terms was the middle bronze age.

The emerging picture of this period is thus taking us beyond a simple denial of Vinča-Troy links, or of Wessex-Mycenae contacts. The developing pattern of radiocarbon dates is creating a new structure, in which the very 


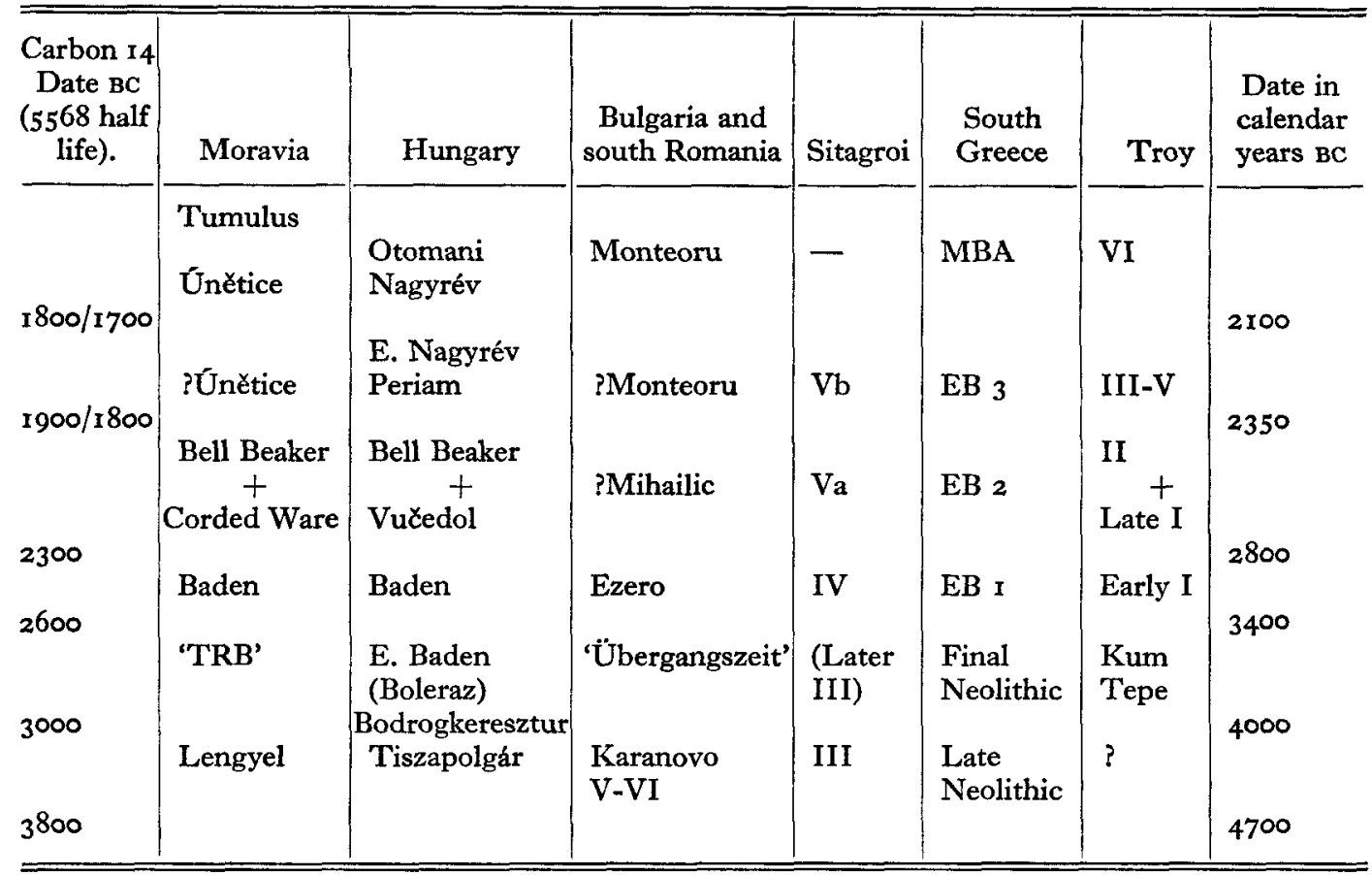

Table 3. Tentative chronological table for the Neolithic-Early Bronze Age transition in south-east Europe

slow formation of the central and east European early bronze age is becoming apparent. In calendar years we must now allow more than I 500 years from the evolution of Tiszapolgár to Nagyrév or Únětice, or from the time of Dhimini to that of Troy II, where until recently most archaeologists would have considered two centuries enough. The long stratigraphy at Sitagroi and the radiocarbon dates from it help, in the north Aegean, to give substance to this long development.

Acknowledgement. In addition to thanking the two radiocarbon laboratories concerned-especially $\mathrm{Dr}$ H. Quitta and Mr Richard Burleigh-I should like to acknowledge the stimulus, more than ten years ago, of discussing the central European early bronze age with Dr John Coles. I am grateful to Mr Andrew Sherratt for information about the Ezero radiocarbon dates.

\section{BIBLIOGRAPHY}

GARAŠANIN, M. v. 1961. The neolithic in Anatolia and the Balkans, Antiquity, 35, 276-80.

KOHL, G. and H. QUITTA. 1966. Berlin Radiocarbon measurements II, Radiocarbon, 8, 27-45.

1970. Berlin Radiocarbon measurements IV, Radiocarbon $12,400-20$.

mellankT, J. 1960. Anatolia and the Balkans, Antiquity, xxxIv, 270-8.

MILojćrć, v. r967. Die absolute Chronologie der Jungsteinzeit in Südosteuropa und die Ergebnisse der Radiocarbon (C 14) Methode, Fahrbuch des Römisch-Germanischen Zentralmuseums Mainz I4, 9 .
MORINTZ, s. and P. ROMAN. I969. Über die Chronologie der UUbergangszeit vom Äneolithikum zur Bronzezeit in Rumänien, Dacia, xIII, 6r-7r.

NEUSTUPNÝ, E. I 968. Absolute chronology of the neolithic and aeneolithic periods in central and south-eastern Europe, Slovenská Archeólogia, XVI, I9-6o.

1969. Absolute chronology of the neolithic and aeneolithic periods in central and south-east Europe II, Archeologické Rozhledy, xxi, 783-81o. QUITTA, H. and G. KOHL. r969. Neue Radiokarbondaten zum Neolithikum und zur Frühebronzezeit Südosteuropas, Zeitschrift für Archäologie, 22355 . 


\section{ANTIQUITY}

RENFrEw, c. I 969 . The autonomy of the south-east European copper age, Proc. Prehist. Soc., $\mathrm{Xxv}, 12-47$.

1970. The tree-ring calibration of radiocarbon: an archaeological evaluation, Proc. Prehist. Soc., XXXVI, 280-3x I.

1972. The Emergence of civilization: the Cyclades and the Aegean in the third millennium $B C$. (London).

SUESS, H. E. r970. Bristlecone pine calibration of the radiocarbon time-scale $5200 \mathrm{BC}$ to the present, in I. U. Olsson (ed.), Radiocarbon variations and absolute chronology, Proceedings of the Truelfth Nobel Symposium.

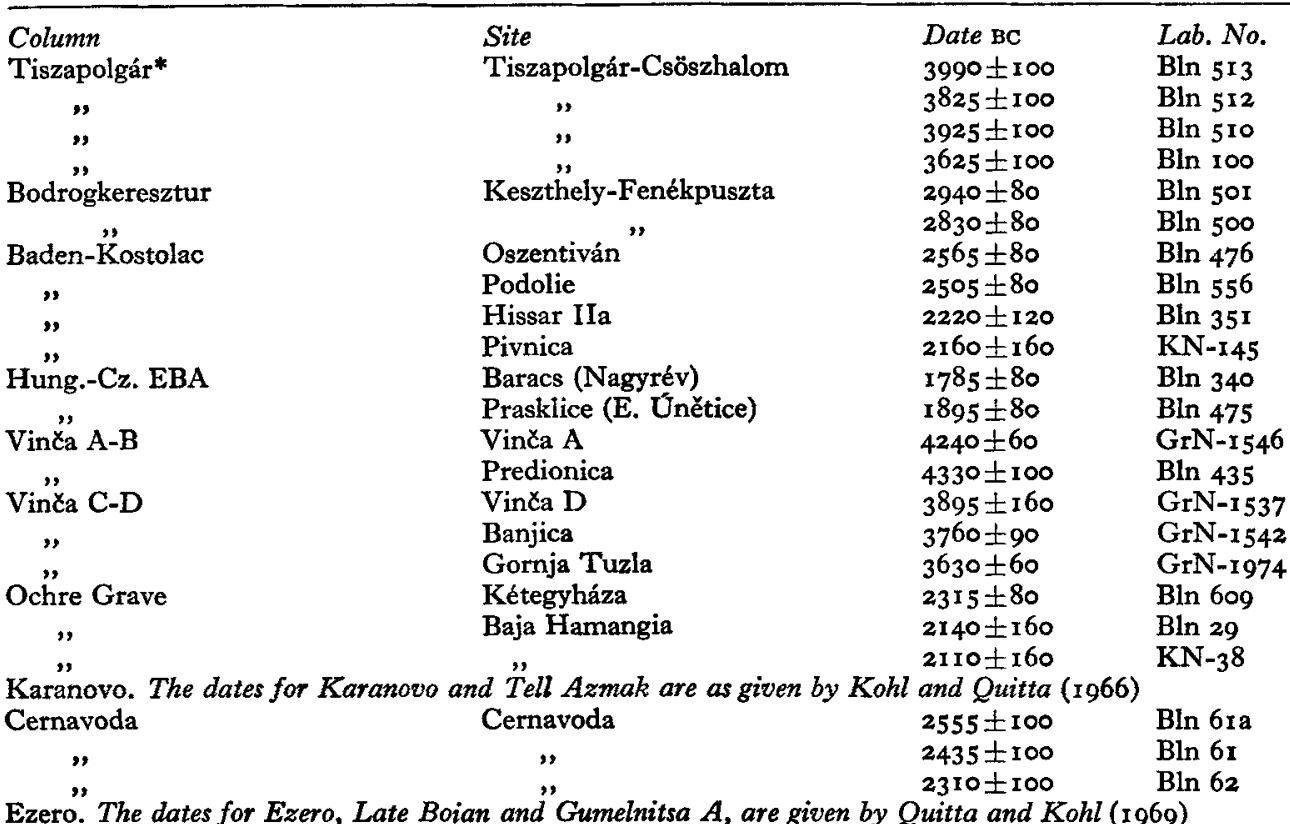

Sitagroi. The dates are given above in Table $I$

\begin{tabular}{|c|c|c|c|}
\hline Knossos & Knossos VI & $4260 \pm 150$ & $\mathbf{B M} 273$ \\
\hline$"$ & , $\quad \mathrm{V}$ & $4190 \pm 150$ & BM 274 \\
\hline 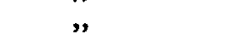 &,$\quad$ IV & $373^{\circ} \pm 150$ & BM 279 \\
\hline Saliagos & Saliagos & $4222 \pm 74$ & $P_{1311}$ \\
\hline " & , & $4124 \pm 79$ & $P=396$ \\
\hline$"$ & $"$ & $3959 \pm 87$ & $P \times 368$ \\
\hline " & , & $3^{825} \pm 84$ & $P_{1333}$ \\
\hline & & $3766 \pm 85$ & $P_{1393}$ \\
\hline Dhimini & Dhimini & $3680 \pm 150$ & $\mathrm{H}=$ \\
\hline Kephala & Kephala (Kea) & $2876 \pm 56$ & $P_{1280}$ \\
\hline Early Helladic I & Eutresis & $2496 \pm 69$ & $P_{306}$ \\
\hline & & $2492 \pm 57$ & $P_{307}$ \\
\hline Early Helladic II & Eutresis & $2262 \pm 56$ & $P 317$ \\
\hline " & Lerna & $2120 \pm 65$ & P 318 \\
\hline " & $"$ & $2031 \pm 64$ & $P_{321 a}$ \\
\hline ", & " & $2027 \pm 59$ & $P 319$ \\
\hline$"$ & ", & $1946 \pm 58$ & $P 321$ \\
\hline$" n=0$ & , & $1887 \pm 65$ & P 312 \\
\hline Early Helladic III & Lerna & $1919 \pm 53$ & P 300 \\
\hline & & $1803 \pm 93$ & P 299 \\
\hline Early Minoan II & Myrtos & $2192 \pm 80$ & $Q_{953}$ \\
\hline$"$ & $"$ & $1855 \pm 85$ & Q 950 \\
\hline T" & " & $1785 \pm 80$ & Q 951 \\
\hline Late Troy I & Emborio IV & $2025 \pm 92$ & $P_{273}$ \\
\hline
\end{tabular}

Table 4. List of dates used in Figure 1 (folder, opposite). *Note that the dates for Tiszapolgár-Csöszhalom precede the full Tiszapolgár culture of the copper age. 